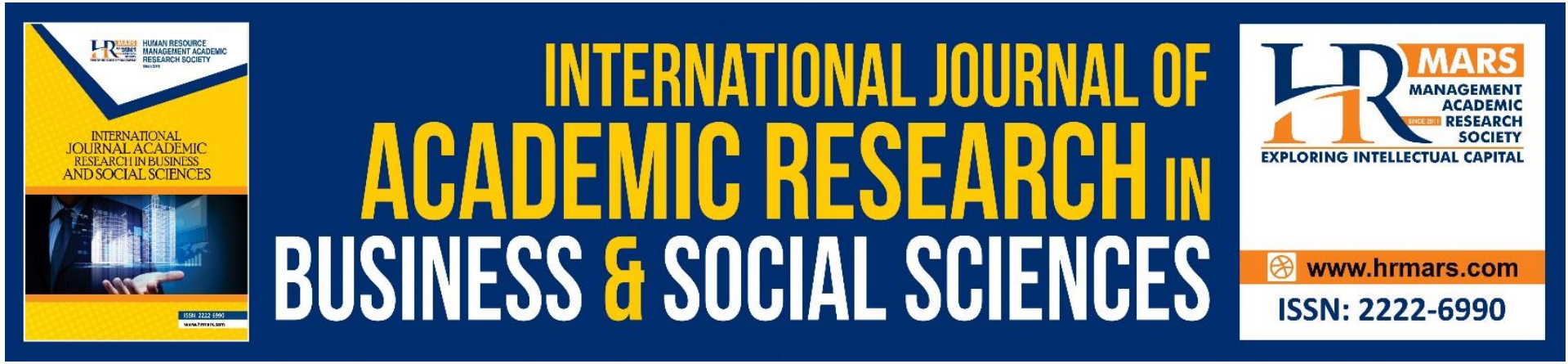

\title{
Language Learning Strategies Used in Improving Writing Skills by Selected Form 4 ESL Learners
}

Nor Azah Sarip@Khalid, Wan Nazira Che Nor, Nor Nadiah Mazelan, Norizarina Mohd Khalid, Nordiana Salim, Harwati Hashim

To Link this Article: http://dx.doi.org/10.6007/IJARBSS/v11-i7/10067

DOI:10.6007/IJARBSS/v11-i7/10067

Received: 12 May 2021, Revised: 18 June 2021, Accepted: 27 June 2021

Published Online: 06 July 2021

In-Text Citation: (Sarip@Khalid et al., 2021)

To Cite this Article: Sarip@Khalid, N. A., Nor, W. N. C., Mazelan, N. N., Khalid, N. M., Salim, N., \& Hashim, H. (2021). Language Learning Strategies Used in Improving Writing Skills by Selected Form 4 ESL Learners. International Journal of Academic Research in Business and Social Sciences, 11(7), 110-124.

Copyright: @ 2021 The Author(s)

Published by Human Resource Management Academic Research Society (www.hrmars.com)

This article is published under the Creative Commons Attribution (CC BY 4.0) license. Anyone may reproduce, distribute, translate and create derivative works of this article (for both commercial and non-commercial purposes), subject to full attribution to the original publication and authors. The full terms of this license may be seen at: http://creativecommons.org/licences/by/4.0/legalcode

Vol. 11, No. 7, 2021, Pg. 110 - 124

Full Terms \& Conditions of access and use can be found at http://hrmars.com/index.php/pages/detail/publication-ethics 


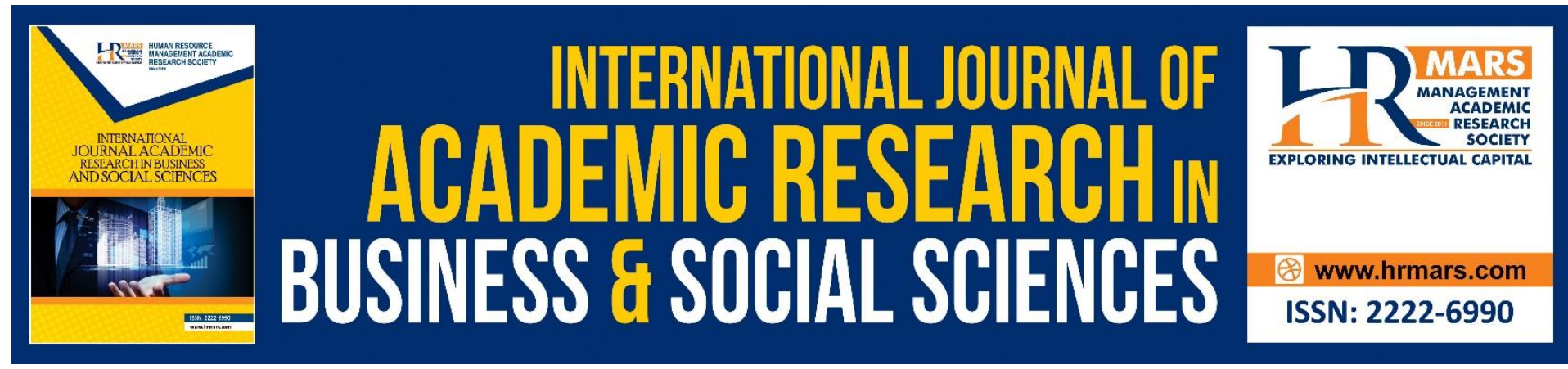

\title{
Language Learning Strategies Used in Improving Writing Skills by Selected Form 4 ESL Learners
}

\author{
Nor Azah Sarip@Khalid, Wan Nazira Che Nor, Nor Nadiah \\ Mazelan, Norizarina Mohd Khalid, Nordiana Salim, Harwati \\ Hashim \\ Faculty of Education, Universiti Kebangsaan Malaysia \\ Email: chewannazira@gmail.com
}

\begin{abstract}
Language learning strategies (LLS) are very important in improving language skills especially writing. Having good writing skills is an attribute of a successful language learner. Certain learners will employ different learning strategies to acquire the skills. As writing is a crucial part in language learning, exploring the language learning strategies by ESL learners are worth reviewing especially in the context of young adult learners. Therefore, this study aimed to identify and explore the LLS commonly used to improve English writing by form 4 ESL learners in a secondary school in Penang. 30 students were purposely selected as the respondents in the study. A questionnaire adapted from Strategy Inventory for Language Learning (SILL) by Oxford (1990) was distributed to the students to identify their use of strategies in improving writing skills. The questionnaire was divided into two parts, with the first part aimed to gain demographic information about the learners and the second part, that consist of 30 items, attempted to obtain data about the strategies used. The respondents were required to respond to the items with a Likert scale of 1 to 4 points. The data collected was analysed with SPSS 26 software application and discussion of the findings was done. The findings revealed that metacognitive strategies are the most frequently applied strategies while affective strategies are the least applied in improving English writing skills by the Form 4 ESL learners. For further research, it is recommended to conduct a study to determine the factors affecting the LLS used by the ESL learners.
\end{abstract}

Keywords: Language Learning Strategies (LLS), English Writing, Direct Strategies, Indirect Strategies, Education

\section{Introduction}

Writing is one of the skills in English language teaching and learning and it has been taught to them since they first learned the language. Graham, Gillespie and McKeown had stated that writing is important as it can be used not only in learning but also in voicing out thoughts and opinions for many purposes. Teaching and learning writing in schools usually focused on the content of the writing. Teachers and students often sit and discuss the content together by focusing on a particular topic. The outcome of the brainstorming session is that the points and contents discussed will be included in the students' writing (Razali, 2013). The 
brainstorming strategy is being continued by the students when they enter higher education institutions.

Despite the fact that students have been exposed to writing skills and strategy from an early age, learners of English still consider writing as a complex and complicated skill. Moreover, in any language, the structure of a language greatly depends on writing, however most of the time, writing skill was not introduced until other skills have been covered. This is because writing is complex and requires specific techniques. English, being the second or probably third language for the students, makes it even harder for them to master writing skill. Due to the complexity of writing skills, in order to help students to understand and create a connection between writing skills and other language skills, learning strategies are needed. This is to help them to be able to identify the strategy that is most suitable for them in acquiring and mastering writing skill (Zuhairi \& Umamah, 2016). Much research has been done on the strategies that students employed in learning writing skills. Bailey (2019) in his research paper discussed how writing strategy research continues to stay relevant in language studies as these strategies need to always be updated, in line with the advancement of the writing environment and technology tools.

Language learning strategies are defined as strategies that contribute to the development of the system of language in which learners construct and affect learning directly (Rubin, 1987). Other researchers like O'Malley and Chamot (1990) defined learning strategies as the thoughts and behaviours that individuals apply to facilitate them in comprehending, learning and retaining new knowledge. Studies have found out that language learning strategies not only facilitate language learning, but it also helps to increase learner-directed learning process. Studies on language learning strategies will help educators to produce insights that can be used to guide learners (Lee and Heinz, 2016).

In the field of language learning, the strategies are classified into two types which are direct strategies and indirect strategies (Oxford, 1990). Direct strategies consist of memory, cognitive and compensation strategies and these strategies have a direct connection to language use, while indirect strategies do not have a direct connection to language use but are equally important in improving language learning. The indirect strategies are metacognitive, social and affective strategies.

The purpose of this research is to study the strategies that were employed by students in learning writing skills. The most used and least strategies employed by the students were investigated. Thus, the findings would help teachers improve and highlight students' preferred language learning strategies in improving their writing skills.

Research Objectives

- To identify the most used language learning strategy among the Form 4 students of a secondary school in Penang in learning English writing

- To identify the least used language learning strategy among the Form 4 students of a secondary school in Penang in learning English writing

Research Questions

- What is the most used language learning strategy among form 4 students of a secondary school in Penang in learning English writing?

- What is the least used language learning strategy among in form 4 students of a secondary school in Penang in learning English writing? 


\section{Literature Review}

In direct learning strategies, there are memory strategies, cognitive strategies and compensation strategies (Oxford, 2003). In memory strategies, learners are helped to make links on the second-language item or concept with another yet do not involve comprehension process. These types of strategies are also related to the involvement of the mental processes in storing new knowledge and information in the memory and through retrieving processes whenever necessary. There are various memory-related strategies which enable learners in learning and retrieving information through orderly strings such as acronyms, while the other techniques focus on creating learning and retrieval through sounds such as rhyming words. Apart from that, memory strategies also include the use of images which create a mental picture of the words or associated definition of them and the use of sounds and images combination such as the keyword method. Moreover, the use of body movement as total physical response and mechanical means like the use of flash cards were also the example of memory strategies (Oxford, 2003).

The cognitive system in humans allows the information obtained to be processed and this system works continuously. Every activity done by humans requires a flow of information and the activity will contribute to the development of skills and building of knowledge schemes (Di Carlo, 2017). Ellis (2006) defines cognitive strategies as those that are involved in the analysis, synthesis or transformation and learning materials. Cognitive strategies have a direct connection with input formation (O'Malley and Chamot, 1990). This strategy involves thinking processes, followed by other sub-strategies, namely practicing, analysing and reasoning, summarizing information, repeating, and recognizing and using formulas and patterns (Nordin, Razak and Kassim, 2020). This strategy manipulates learning sources directly in terms of translation, note taking, summarizing and highlighting.

Another strategy commonly used in language learning is compensation strategies. Wu (2008) mentioned that learners are able to understand, comprehend a second language by translating, using synonyms or antonyms, coin words, select topics and use a dictionary in order to write meaningfully. In addition, Maharani et. al (2018) revealed that compensation became the dominant strategy for the students with poor writing production while it became the most famous or high frequency of strategy used for the students with good writing production. Hence, this strategy is beneficial and helpful to improve and cultivate students' motivation and potential in learning the target language (Griffiths \& Parr, 2001). Further, Oxford (1990) as cited in Wu (2008) agreed, this strategy is important to make up for their missing knowledge as well as for effectively producing the target language.

Metacognitive strategies allow the learners to have control on their own cognition through the use of several strategies which include arranging, evaluating, lowering anxiety and seeking opportunities. Metacognitive strategies were also commonly known to involve the process of planning, making decisions in choosing how they learn and finally to evaluate their learning (O'Malley, Chamot \& Kupper, 1987). O'Maley et al. as cited in Zane (2012) further claim that these strategies involve expression in indicating an executive function and strategies such as planning for the learning, thinking about the process of learning and observing the comprehension and production, making correction of any mistakes and to evaluate the learning process. This corroborates Ellis, Denton, \& Bond (2014) when they suggest that the stages of the learning process involve three other processes which are planning, monitoring, and evaluating. 
According to Oxford (2017), there are three components of affective strategies: lowering your anxiety, encouraging yourself, and taking your emotional temperature. For the first component, which is lowering your anxiety, learners can use relaxation processes like meditation, deep breathing, listening to music and laughter to lower and control their anxiety. The second component, which is encouraging yourself, allows learners to do positive self-talk to encourage themselves, take risks wisely and praise or reward themselves for their achievement. The last component is taking your emotional temperature. The third component consists of writing a language learning diary and discussing feelings with someone else. These aspects of supportive emotions, motivation and positive attitudes are very essential in helping learners learn a new language (Oxford, 2011). Learners are given the power to control their feelings and emotions in language learning and learn at their own pace. Oxford (2011) suggested these strategies to be applied for learners who have low motivation and problem with their emotions in learning a language. Indirectly, learners will be more motivated and less anxious when applying these strategies. In short, affective strategies are mainly about emotion, attitudes, and motivation.

The last indirect strategy is social strategy (Oxford \& Burry-Stock, 1995). While social strategy is placed under indirect strategy, Oxford (1990) mentions it to have indirect contribution yet it is still impactful towards learning. Social strategy would allow students a direct assessment towards their own learning where they could report their own degree of having control within the learning environment (Benson, 2011). One of the effects of social strategy is to become the deliberating factor in interaction within the environment where it usually indicates discourse situation (Oxford, 1990). As the term 'social' may refer to, interlocutors may start probing answers by exchanging questions. There would also be some levels of cooperation among them and at the same time the exchanges happen within the border of empathizing among each other. In the end, social strategy allows some levels of communicative interactions whereby it relates to the other strategies as well (Oxford, 1990).

\section{Research Design}

This research aims to identify the most widely and least used language learning strategies (LLS) among Form 4 students in a secondary school in Penang. A survey study which involves 30 questions related to the LLS together with Likert Scale was used. The questionnaires were conducted through Google form due to the Covid-19. The research utilized Oxford's (1990) 7.0 edition of Strategy Inventory for Language Learning (SILL) which is commonly known as the most reliable and acknowledged tool in identifying LLS.

\section{Instrument}

Strategy Inventory for Language Learning (SILL) version 7.0 was utilized in the research in collecting the information aligned with the desired objectives. SILL is a type of a survey tool developed by Oxford (1990) and it is a highly comprehensive and reliable tool in investigating learning strategies employed by the learners (Lee, 2010). Habok and Magyar (2018) further supported this statement by claiming that this instrument suits to be utilized as the taxonomy to assess the strategy that ESL/EFL are using. In addition, through this instrument, students reflect on the extent they are using various language strategies. The statements were also translated into the participants' first language which is Malay so as to enhance their understanding and to prevent any misunderstanding of the statements. Basically, the questionnaire has 30 statements which consist of 5 statements for each strategy. There are five statements for each Language Learning Strategies in the questionnaire: 
Table 1: Description for the Statements in the Questionnaire.

\begin{tabular}{cc}
\hline Statement & Description \\
\hline Statement 1-5 & Memory Strategy \\
Statement 6-10 & Cognitive Strategy \\
Statement 11-15 & $\begin{array}{c}\text { Compensation } \\
\text { Strategy }\end{array}$ \\
Statement 16-20 & Metacognitive \\
Strategy \\
Statement 21-25
\end{tabular}

All the statements were then rated on a Likert scale of 1-4 to signify the extent or degree of how much the participants agree or disagree for each statement based on their own experiences in the classroom on the use of LLS. The Likert scale was described as below:

Table 2: Description of the Likert Scale for each Statement of Language Learning Strategy Scale Description

$\begin{array}{cc}1 & \text { Never or almost never true of me } \\ 2 & \text { Usually not true of me } \\ 4 & \text { Usually true of me } \\ 4 & \text { Always or almost always true of } \\ \text { me }\end{array}$

\section{Samples}

Purposive sampling was implemented in selecting the participants for the research. The participants are all in intermediate level in terms of their English proficiency. By using this group of participants, the data gathered and collected were valid and reliable since a homogeneous group was involved. Moreover, there were 30 participants involved in the research which consisted of six male and twenty four female participants.

\section{Data Collection Method}

A quantitative analysis was implemented for the data collection method. The data was obtained by percentage which was automatically calculated by the "Google form". The data was collected directly after the participants submitted their responses online. 


\section{Data Analysis}

A descriptive study was implemented for the results of the most and least used language learning strategy by the participants. The mean of each technique in the strategy was calculated and followed by the total mean of each strategy. Comparison of the most used and the least among the techniques in every strategy were analysed. In addition, comparison of the most used and the least strategy applied by the participants were also compared and analysed prior to interpretation.

\section{Findings}

\section{Memory Strategy}

Table 3 below indicates the findings for memory strategy.

\begin{tabular}{l|c}
\hline \multicolumn{1}{c|}{ Statement } & Mean \\
\hline 1) I think of the relationships between what I already know and new things & 3.23 \\
I learn in English during the writing process. & 2.8 \\
2) I use/write new English words in a sentence so I can remember them. & 3.13 \\
3) I connect the sound of an English word and an image or picture of the \\
world to help me remember the word. & 2.27 \\
4) I use flashcards to remember new English words so that I can use them \\
in my writing. & 3.2 \\
5) I review English lessons often to enhance my memory of the words \\
learned.
\end{tabular}

As shown in table above, the total mean of memory strategy is 2.93. The highest technique of memory strategy implemented was Statement 1 (I think of the relationships between what I already know and new things I learn in English during the writing process.) and Statement 5 (I review English lessons often to enhance my memory on the words learned.). On the other hand, the participants seemed not to really use flashcards to remember new English words in their writing as in Statement 4. 


\section{Cognitive Strategy}

Table 4 below indicates the findings for cognitive strategy

\begin{tabular}{l|l}
\hline \multicolumn{1}{c|}{ Statement } & Mean \\
\hline 1) I use new vocabulary repeatedly in my writing. & 2.83 \\
2) I analyze sentence structure and use it in my writing. & 2.93 \\
3) I use the same sentence pattern and structure in my writing. & 3.03 \\
4) I read English reading material and use the sentences in my writing. & 3.23 \\
5) I make summaries of information (that is relevant to my writing) that I & 3.2 \\
hear or read in English. & $\mathbf{3 . 0 4}$ \\
\hline
\end{tabular}

The table above shows the total mean of 3.04. From the result, the technique that students applied in learning writing was reading English materials and using the sentences in their own writing (3.23), followed by making summaries of information that is relevant to their writing (3.2). Meanwhile, the technique that they used the least was using new vocabulary repeatedly in their writing (2.83).

\section{Compensation Strategy}

Table 5 indicates the finding for compensation strategy.

\begin{tabular}{l|c}
\hline \multicolumn{1}{c|}{ Statement } & Mean \\
\hline 1) I translate the sentences from L1 to L2 in writing. & 3.37 \\
2) I would think of another similar word if I can't think of the word in English \\
I need for writing. & 3.36 \\
3) I look up the words in the dictionary if I'm not sure of their meaning. & 3.40 \\
4) I guess the meaning by using linguistic clues. & 2.97 \\
& 3.27 \\
5) I write new sentences if I don't know the right ones in English. & 3.27 \\
\hline
\end{tabular}

The total mean of compensation strategy, (3.27) indicates that usually true participants use and apply a compensation strategy in their writing activity. The technique they often used was number 3 whereby the participants looked up the meaning of the words in the dictionary 
if they were not sure with certain words. The least techniques preferred by participants is guessing meaning by using linguistic clues.

\section{Metacognitive Strategy}

Table 6 below indicates the findings for metacognitive strategy.

\begin{tabular}{l|c}
\multicolumn{1}{c|}{ Statement } & Mean \\
\hline 1) I identify my preferred learning style and needs when I do my writing. & 2.83 \\
2) I plan for my writing task. & 3.07 \\
3) I gather and organize necessary materials during writing activity. & 3.20 \\
4) I monitor my mistakes during the writing activity. & 3.17 \\
5) I evaluate my writing. & 3.23 \\
& 3.88 \\
\hline
\end{tabular}

As shown in table above, the total mean of metacognitive strategy is 3.88 which indicates that it was always or most always true of the participants to apply and implement metacognitive strategies during their writing activity. The highest technique of memory strategy implemented was Statement 5 whereby participants were most always evaluated their writing. However, the participants used the least of identifying their preferred learning styles and needs when they do their writing as in Statement. 


\section{Affective Strategy}

Table 7 below indicates the findings for affective strategies.

\begin{tabular}{l|c}
\hline \multicolumn{1}{|c|}{ Statement } & $\begin{array}{c}\text { Mea } \\
\mathrm{n}\end{array}$ \\
\hline 1) I try to overcome the feelings of anxiety whenever I do my writing task. & 3.13 \\
2) I reward myself when I'm given a good grade in my writing task. & 2.50 \\
3) I motivate myself to keep writing by saying "come on", "go on", "you can do & 3.30 \\
it". & 1.77 \\
4) I write down my feelings in a language learning diary. & \\
5) I talk to someone else about how I feel when I am doing my writing task. & 2.80 \\
\hline Total mean & $\mathbf{2 . 7 0}$ \\
\hline
\end{tabular}

As shown in the table above, the total mean of affective strategy is 2.70 . The most frequently used technique in affective strategy was Statement 3 where participants motivate themselves to keep writing by saying 'come on', 'go on', and 'you can do it'. In contrast, the least frequently used technique was Statement 4, which is writing down feelings in a language learning diary. 


\section{Social Strategy}

The table below shows the results from social strategy.

\begin{tabular}{l|c}
\multicolumn{1}{c|}{ Statement } & Mean \\
\hline a) I ask my teacher to give feedback on my writing. & $2 . .87$ \\
2) I ask my classmates to give feedback on my writing & 3.03 \\
a) I discuss with more advanced learners when doing writing task & 3.5 \\
a) I read the writing by my classmates to get more ideas & 2.47 \\
a) I am willing to discuss the writing task done by my classmates & 2.87 \\
& 2.95 \\
\hline
\end{tabular}

The table above indicates the total mean for social strategies which is 2.95 . The most frequent technique favoured by participants is to discuss their writing task with more advanced learners. This chosen statement is particularly unique as it reveals that discussion and collaboration is more favoured by students when facing writing tasks that are in nature is more of an individual task.

\section{Discussion}

\section{Research Question 1}

What is the most used language learning strategy among form 4 students of a secondary school in Penang in learning English writing?

Based on the findings above, metacognitive strategies are the most applied strategies among the Form 4 learners in learning English writing resulting in mean 3.88. The items under metacognitive strategies are as follows, (1) I identify my preferred learning style and needs when I do my writing, (2) I plan for my writing task, (3) I gather and organize necessary materials during writing activity, (4) I monitor my mistakes during the writing activity, (5) I evaluate my writing. The language learners have shown predilection towards the application of metacognitive strategies which may infer that they want to impart their own identity and academic control on the written compositions. This is evident based on Wenden (1991) who states that these strategies depict mental operations or procedures chosen and used by learners to place certain regulation in their learning. While their piece of written works may not be perfect, they would opt for self-regulation to guide their evaluation of the writing task. Goctu (2017) further stated that metacognitive strategies are utilized to help manage the process of learning where they involve identifying an individual's unique learning style, planning for a task in second language, collecting and reviewing materials, monitoring possible errors and evaluation of successfulness of task at hand. Relatively, students who 
adorn the strategies have higher form of self-evaluation in managing the requirements of the task. They would experience better self-satisfaction when they could figure out what are their aspirations of the task. This could explain why strategy number 5 is the mostly chosen strategy with mean 3.23.

Evidently, the strategies that are also the most popular aside those that indicate selfmanagement in completing writing is strategy number 3 where most of the participants take their task seriously and make the efforts to gather and organize necessary materials during writing activity. This may explain that they are using their cognitive abilities to deliberate their options in task completion. It could also be safely assumed that they have the tendency to think forward on the task and not only resorting to the last option of simply doing the writing task to avoid subject failure. In relation to this, Purpura (1999) has also emphasised that when it comes to native speakers of English, metacognitive strategies are related directly to cognitive strategy where they pose meaningful and positive effect which explains further the executive functions of metacognitive strategies in completing a task. In the context of the study, as the participants are acquiring and learning the same language, they do have the makings of good language learners.

In metacognitive language learning strategies, learners possess the foundation towards comprehending learning process of writing in English. Goctu (2017) also points out that the essential position of metacognitive strategies can be seen when it is one of the terms used in Information Processing Theory as to stress on the executive function where this strategy means that learners place some efforts to manage, monitor and evaluate themselves. For example, when faced with writing tasks, learners would take their own time to understand the requirement of the task. They do so sensibly while considering the limited time window that they have. They would also prone to checking their written texts by reading through the flow, connecting the ideas, the elaborations and the sentences within suitable vocabularies. These steps help guide their writing which makes them a better writer from time to time.

\section{Research Question 2}

What is the least used language learning strategy among in form 4 students of a secondary school in Penang in learning English writing?

As proven from the findings, the least used strategies are affective strategies. Encompassed within the strategies are as follows, (1) I try to overcome the feelings of anxiety whenever I do my writing task, (2) I reward myself when I'm given a good grade in my writing task, (3) I motivate myself to keep writing by saying "come on", "go on", "you can do it", (4) I write down my feelings in a language learning diary, (5) I talk to someone else about how I feel when I am doing my writing task. With the lowest mean score of 2.7, these strategies are the least favoured strategies among the learners. According to Oxford (2017), a few components are built up into the affective strategies. They are lowering one's anxiety, encouraging oneself and taking one's emotional temperature. For the first component, it is indicated that learners can use relaxation process such as meditation, deep breathing, listening to music and laughter to lower and control their anxiety. While participants opt for strategy number 1 which is on overcoming anxiety, they will not discuss their feelings of anxiety when strategy number 4 records the lowest mean which is 1.77. It is thus arguable- could learners be relied to cope with their anxiety if they do not easily expose their true nature of learning writing which for some is considered a demanding task?

The second lowest mean is on strategy number 2 where only a few learners choose to reward themselves when they finally achieved the good grade they have been working hard for. 
Oxford (2011) stresses the aspects of supportive emotions, motivation and positive attitudes hold a central position in helping learners learn a new language. With the mean of 2.5 , most learners may not really see themselves as deserving of self-praise and special gestures when they achieve their target. While it may seem that they focus on the task more than rewarding themselves, this response may point out that they have low motivation (Oxford, 2011). They may somehow assume that their work is not really that good to be considered and thus, why the reward? This is an unpleasant scenario to take place among learners as learning and acquiring language especially on English writing has started since their kindergarten years. They are hoped to develop their own liking of the activity and thus see themselves and improving from day to day. In short, as affective strategies concern learners' emotions, attitudes and motivation, having the aspects placed and nurtured within learners' selfconcept could drive reliable changes in reviewing themselves doing writing tasks in the future. Reasonably, it could be seen that learners are still far from having good opinions and the right concept of emotions about themselves in undergoing English writing challenges. From time to time, learners require aspiration, inspiration and motivation from their teachers to help see their own importance in developing their English writing skills through affective strategies of language learning. The future workplace demands may not be so keen to consider their views on the matter; and thus, it is on teacher's responsibility as well to play their role.

\section{Limitations}

The main aim of the study was to identify, analyse and explore the LLS commonly used by form 4 learners in a secondary school in Penang in learning English writing. Some limitations in the study need to be highlighted although the survey was conducted thoroughly. First of all, the small size of participants makes it difficult to identify the relationships between the different variables. Since the sample size is small and the aim of this study is to identify the strategies used by the participants, thus the data analysed cannot be related to other variables such as gender factor. When using questionnaires in a survey, another possible problem is that the participants might have different interpretations of the questions. The differences in cultural background and home environment might influence the participants' view and idea of LLS. Furthermore, as the participants were purposely chosen from the target school, the findings of the study cannot be interpreted to other populations or generalised to a wider similar population.

\section{Conclusion}

This research was conducted to know language learning strategies used by form 4 learners in a secondary school in Penang particularly in learning English writing. Based on the findings, it can be concluded that the learners used all the six categories in LLS which are memory, cognitive, affective, metacognitive, compensation and social strategies but at different frequencies. The strategy that has the highest rate of usage by the learners is metacognitive strategy while the least frequently used strategy is affective strategy. From the findings, the learners apparently use direct and indirect strategies in learning English writing. In learning language skills, learning strategies are very important to become successful language learners.

Since this research only identified the learning strategies of a small group in a particular secondary school, further research should be conducted at an earlier level such as in primary school to assist learners to become effective language learners. Future researchers 
can apply other instruments like a semi-structured interview to explore more in-depth information from the learners.

\section{References}

Bailey, D. R. (2019). Conceptualization of second language writing strategies and their relation to student characteristics. Journal of Asia TEFL, 16(1), 135.

Benson, P. (2011). Teaching and Researching Autonomy. Great Britain: Pearson Education Ltd.

Di Carlo, S. (2017). Understanding cognitive language learning strategies. International Journal of Applied Linguistics and English Literature, 6(2), 114-126.

Ellis, N. C. (2006). Cognitive perspectives on SLA: The associative-cognitive CREED. Aila Review, 19(1), 100-121.

Ellis, A. K., Denton, D. W., \& Bond, J. B. (2014). An analysis of research on metacognitive teaching strategies. Procedia - Social and Behavioral Sciences, 116, 4015-4024. https://doi.org/10.1016/j.sbspro.2014.01.883

Goctu, R. (2017). Metacognitive strategies in academic writing. Journal of Education in Black Sea Region, 2(2), 8-9.

Graham, S., Gillespie, A., \& McKeown, D. (2013). Writing: Importance, development, and instruction. Reading and Writing, 26, 1-15.

Griffiths, C., \& Parr, J. M. (2001). Language-learning strategies: Theory and perception. ELT journal, 55(3), 247-254.

Lee, C. K. (2010). An overview of Language Learning Strategies. Annual Review of Education, Communication, and Language Sciences 7:132-152

Lee, J., \& Heinz, M. (2016). English language learning strategies reported by advanced language learners. Journal of International Education Research (JIER), 12(2), 67-76.

Maharani, S., Fauziati, E., \& Supriyadi, S. (2018). An Investigation of writing strategies used by the students on the perspective language proficiency and gender. International Journal of Multicultural and Multireligious Understanding, 5(5), 185-190.

Nordin, L., Razak, N. Z. A., \& Kassim, R. (2020). Direct learning strategies employed in learning english among students of engineering technology. Journal of Critical Reviews, 7(8), 162-167.

O’Malley, J. M., Chamot, A. U., \& Kupper, L. (1987, June). The role of learning strategies in second language acquisition: Strategy use by students of English. Retrieved from http://www.dtic.mil/dtic/tr/fulltext/u2/a192006.pdf

Oxford, R. L. (1990). Language Learning Strategies: What Every Teacher Should Know. California: Newbury House Publisher.

Oxford, R. L., \& Burry-Stock, J. A. (1995). Assessing the use of language learning strategies worldwide with the ESL/EFL version of the Strategy Inventory for Language Learning (SILL). System, 23(1), 1-23.

Oxford, R. L. (2003). Language learning styles and strategies: An overview. GALA, $1-25$.

Oxford, L. R. (2011). Teaching and researching language learning strategies. New York: Pearson Education Limited.

Oxford, L. R. (2017). Teaching and researching language learning strategies: Self-regulation in Context. New York: Routledge.

Purpura, J. (1999). An analysis of the relationships between test takers' cognitive and metacognitive strategy use and second language test performance. Language Learning, 47, p. 289-325. 
Razali, A. B. M. (2013). Malaysian teachers' conceptions and uses of digital technology in English writing instruction: A multiple case study. Michigan State University.

Rubin, J. (1987). Learner strategies: Theoretical assumptions, research history and typology. Learner strategies in language learning, 15-30.

Wenden, A. (1991). Metacognitive strategies in L2 Writing: A case for task knowledge. J. E. Alatis (Ed.), Georgetown University Round Table on Languages and Linguistics, p. 302-321.

$\mathrm{Wu}, \mathrm{Y}$. L. (2008). Language learning strategies used by students at different proficiency levels. Asian EFL Journal, 10(4), 75-95.

Zane, P. (2012). Language Learning Strategies among EFL/ESL Learners: A Review of Literature. International Journal of Humanities and Social Science, 2 (5).

Zuhairi, A., \& Umamah, A. (2016). The Indonesian junior high school students' strategies in learning writing skill. Arab World English Journal (AWEJ) Volume, 7. 